\title{
CAPITAL THEORY, INFLATION \\ AND DEFLATION: \\ THE AUSTRIANS AND MONETARY \\ DISEQUILIBRIUM THEORY COMPARED
}

BY

\section{STEVEN HORWITZ}

\section{INTRODUCTION}

At one level or another, economic processes make it possible for diverse individuals to coordinate their activities. Although microeconomists have long recognized this insight, and purport to explain it with their tools, macroeconomists often seem to lose sight of the centrality of coordination when they focus on the movements of, and relationships among, aggregate variables. One problem with emphasizing aggregates is that, in reality, economic coordination ultimately takes place at the microeconomic level, which poses the issue of microfoundations. However, recognizing that micro issues are the fundamental ones does not deny a role for distinctly macroeconomic analysis. Macroeconomic analysis should show how movements in markets for goods that are pervasive (i.e., affect some very large number of microeconomic markets simultaneously), help or harm the coordination processes taking place in those individual markets and thus influence the determination of aggregate measures such as total income and employment.

In particular, two of the most pervasive phenomena such analyses will have to consider are time and money (Garrison 1984). A macroeconomics with coordination-based microfoundations would focus on movements in the markets for (savings, investment and interest rates) and money (money supply and demand, banking institutions, and market rates of interest).

St. Lawrence University, Canton, NY. The author would like to thank Bill Butos, Roger Koppl, Bill Woolsey, Don Lavoie, Peter Boettke, Robert Greenfield, numerous seminar participants and several anonymous referees for comments on earlier drafts. I am grateful for the generous support of the Earhart Foundation.

Journal of the History of Economic Thought, 18, Fall 1996.

O1996 by the History of Economics Society. 
Specifically, it would analyze how disequilibria in the money and time markets can affect the array of relative prices, including intertemporal ones, throughout the economy, and see if any systematic patterns of error result. In addition, a coordination-based macroeconomics would need to take explicit account of the capital structure both in its role in maintaining intertemporal coordination and as a process through which monetarilyinduced discoordination might reveal itself.

It can be argued that two apparently divergent macroeconomic schools of thought that have persisted in the history of economics are both part of a larger theoretical view which is capable of meeting most of these criteria. The Austrian theory of the trade cycle as described by Ludwig von Mises $(1912,1966)$ and F. A. Hayek $(1933,1935,1939)$ and the "pre-Keynesian" monetary disequilibrium theory of deflation of Clark Warburton (1946 and 1966), Herbert Davenport (1913), Leland Yeager (1986), and Robert Greenfield (1994) both analyze ways in which microeconomic coordination can be upset by disequilibria in the money and/or time markets. Both theories are part of a consistent line of thought, yet to be fully developed, dating back before Keynes, known as monetary equilibrium theory. The Austrian theory and the monetary disequilibrium approach can be seen as explaining the consequences that follow from the two possible cases (inflation and deflation) in which monetary equilibrium is not maintained.

After a review of both theories, we will see that one key source of their differences is how each theory has or has not treated capital. Recognizing the importance of a theory of capital for a theory of monetary disequilibrium also sheds new light on issues such as the neutrality of money and ideal bank policy. A monetary equilibrium perspective, specifically as laid out by George Selgin (1988, ch. 4) and enhanced by insights from Austrian capital theory, can provide a framework for reconciling the Austrian and monetary disequilibrium theories.

\section{THE AUSTRIAN THEORY OF THE TRADE CYCLE}

Austrian business cycle theory, as first laid out by Ludwig von Mises (1912), emerged out of the interaction of three sets of influences. Mises combined an Austrian (or perhaps more accurately, Böhm-Bawerkian) theory of capital with Knut Wicksell's analysis of the natural and market rates of interest and tied it to his development of a subjectivist and marginalist approach to money (outlined earlier in The Theory of Money and Credit). To grasp fully the theory that emerged, and to lay the groundwork for a later discussion of the role of capital theory in monetary equilibrium theory, a brief review of Austrian capital theory and Wicks- 
ell's theory of interest is necessary.

The Austrian approach to capital is to see it not as a homogeneous store of productivity, but rather as a interconnected, intertemporal structure that is reflective of the plans of the various actors in an economic system. As Ludwig Lachmann (1978, pp. 2-3) has argued, we cannot simply add up existing capital goods and get a meaningful measure of capital. For one, the very heterogeneity of capital prevents us from finding a common natural unit of measurement. How does one add up a truck and a computer? If we think of using money prices as a measure we have to consider the inconsistencies that will follow. Each piece of capital is part of the plan of some economic unit. Assuming disequilibrium, as Austrians typically do, there is no reason to believe that any given use of a piece of capital is an objectively desirable one. In other words, the plans of economic actors may be mistaken and the current prices of capital goods will reflect those errors, preventing them from being accurate indicators of value. In fact, one of Lachmann's key points in his extension of Austrian capital theory is to emphasize that the structure of capital is constantly changing in the face of the realization of failed plans and actors' subsequent reinterpretations. For Austrians, the capital structure describes economic actors' current perceptions of the plan-relevance of each of their pieces of capital (Lewin 1994).

The capital structure also reflects the temporal dimension, or "roundaboutness," of production. The time it takes to move raw materials and labor to a finished product can be seen as the length of a process of production. This is the clear Böhm-Bawerkian (1923) influence. Although more recent developments of Austrian capital theory have abandoned Böhm-Bawerk's emphasis on the "average" period of production, the idea of the capital structure as reflecting roundaboutness remains. The degree of roundaboutness is linked to the rate of interest. At higher rates of interest we would expect shorter processes of production, as the cost of the time to completion would be higher. Conversely, lower rates of interest should lengthen the capital structure, as the lower cost of time will make more roundabout, and hence more productive, processes more feasible. For Austrians, the capital structure needs to embody some notion of intertemporal coordination, i.e., the lengths of current processes of production should correspond to the willingness of consumers to wait for the availability of consumer goods. If the capital structure is not intertemporally coordinated, so that capital is being misallocated or malinvested, then there is avoidable economic waste.

Central to understanding intertemporal coordination is Wicksell's theory of the market and natural rates of interest as laid out in volume 2 of his Lectures on Political Economy (1935), as well as his earlier Interest and 
Prices (1898). Wicksell (1935, p. 193) distinguishes the two rates the following way. The natural or "normal" rate of interest is "the rate of interest at which the demand for loan capital and the supply of savings exactly agree." The market rate of interest refers to the bank rate, or what is currently being charged for loans in the form of money. Wicksell argues that (ibid., p. 199) that the case of a market rate below the natural rate implies an increase in commodity prices while a market rate above the natural rate will lead to progressively falling commodity prices. For Wicksell, interest rates are inherently linked with changes in the value of money. To avoid these undesirable changes, it is "the obligation of the banks to maintain the rate of interest in agreement with the normal or real rate of interest" (ibid., p. 201). It is from this understanding of the relationship between the two rates of interest, and the desirability of having a market rate that accurately reflects the natural rate that is the expression of intertemporal preferences, that the Austrian theory of the cycle emerged.

The traditional Austrian story is that cause of the divergence between the market rate and the natural rate is the activity of the banking system. ${ }^{1}$ If the banking system expands the supply of money by making more reserves available to individual banks, those banks will have additional loanable funds at their disposal and can, in turn, make new loans. Ceteris paribus, this will mean that banks will have to lower their market rates to attract new borrowers. Assuming that increased supplies of money have no direct and immediate effect on real rates of saving or cause shifts in the demand for loanable funds, there will be no change in the underlying natural rate. As Wicksell's own analysis suggests, this artificial lowering of the market rate will cause commodity prices to rise. Mises, however, took this scenario and turned it into a full-fledged cycle theory.

The key is that entrepreneurs, basing their capital decisions on the lower market rate, lengthen the structure of production, which appears feasible at the lower market rate. As entrepreneurs undertake these longer-term projects, money makes its way to laborers and owners of capital. These groups spend and save this money in accordance with their underlying time preferences, which are in conflict with the signal sent by the market

1. It is curious that in Wicksell's treatment in the Lectures he does not explicitly ascribe the source of the divergence to errors of commission by the banking system. He does discuss the effect of influxes of additional gold, but in other places (Wicksell 1935, p. 206) he talks about the effects of a technological discovery that alters the natural rate without an appropriate response (an error of omission) by the banking system, thus causing a divergence from the natural rate side rather than the market rate side. In some sense this is an embryonic real business cycle story. 
rate. It would be only be the sheerest coincidence that these preferences would have changed by the precise amount and direction of the change in the market rate. Assuming away that possibility, their preferences (which are reflected in the natural rate) are not coordinated with the market rate. More precisely, the market rate is telling entrepreneurs that consumers are more willing to wait for the output of longer production processes, while, in fact, consumers have a relatively higher demand for present goods than entrepreneurs are led to believe by the market rate. This intertemporal discoordination is the linchpin of the business cycle.

Eventually it becomes clear that real savings do not exist to finance the remaining parts of the newly undertaken lengthier capital projects and the bust of the business cycle follows. Entrepreneurs realize that they have been mistaken in their estimates of consumers' intertemporal preferences and are forced to switch back to relatively shorter production processes. Of course this adjustment from longer to shorter processes takes time, and involves various costs of adjustment in retooling capital and retraining labor. Over time, firms adjust and labor is rehired and the economy recovers, given the losses of the cycle.

\section{MONETARY DISEQUILIBRIUM THEORY AND DEFLATION}

The monetary disequilibrium theorists of earlier this century were trying to explain many of the same empirical phenomena as was J. M. Keynes. While Keynes provided an updated underconsumption theory, $\mathrm{H}$. G. Brown, Warburton, Davenport and others told a story about deflation consistent with the Wicksellian framework outlined previously. ${ }^{2}$ In fact, many writers in this tradition explicitly point to Wicksell, for example Axel Leijonhufvud (1981a, 1981b), as the source for the story they tell.

In the monetary disequilibrium story, the banking system fails to produce a sufficient supply of money, reducing bank reserves and restricting their ability to make new loans. With a smaller pooler of funds to loan out, banks are forced to raise their market rates of interest to ration this shrinking supply to an essentially unchanged demand for capital. It should be clear that, to this point, the monetary disequilibrium story is the mirror image of the Austrian theory. According to the monetary disequilibrium theorists, this shrinkage in the money supply, and rise in the market rate, will exert a downward pressure on prices, as Wicksell also argued. The undersupply of money prevents actors from translating

2. The description of deflation that follows is a stylized composite that contains elements from the views of all of the authors cited. Yeager (1986) provides direct textual evidence from these authors for this monetary disequilibrium view. 
their supplies of productive services in to market buying power, thus preventing potential mutually beneficial exchanges from occuring and reducing the level of economic activity (Greenfield 1994, p. 2). This is what Leijonhufvud (1981a, p. 103) calls an "effective demand failure."

The process by which this deflation works is that attempts to buy and sell are frustrated by the lack of money. For example, suppose a firm desires to hire some additional labor. It may be true that the value of each worker's marginal product will just equal the wage the firm intends to pay. And it may be true that if the workers got the job they would spend on other goods and services, but as Leijonhufvud (ibid., pp. 116-17) argues, monetary receipts are a constraint on current expenditures. If there is an excess demand for money, firms simply cannot obtain the money they need to pay labor and the necessity of monetary exchange becomes a binding constraint on their ability to hire workers. Because of the lack of money, potentially hirable workers go unhired and unpaid, and this lack of realized sales of labor constrains the worker's current purchases. The goods they would have bought go unsold, and the additional labor that might have been hired by the selling firm as a result goes unhired (Greenfield 1994, p. 5). This monetarily-constrained process continues and the economy slows down. If workers could barter labor directly for consumption goods, this would not occur. However, the constraint imposed by the need to intermediate exchange with money becomes binding during deflation (Leijonhufvud 1988, p. 211).

The explanation for this Wicksellian cumulative rot is the lag between the fall in the money supply and the need for a corresponding fall in prices and wages. If prices and wages could fall instantaneously, then the cash constraint, at least in the aggregate, would not be so binding. Indeed, actors would find themselves with smaller nominal money balances, but the instantaneous adjustment of prices and wages would ensure that their new lower nominal holdings were appropriate real balances. Deflation causes the rot by driving a wedge between notional and effective demand which is caused by prices and wages not adjusting quickly enough. All of the effects of the monetary disequilibrium story come about because of this lag and these effects are revealed in the general economic slowdown that results.

\section{CAPITAL THEORY, NEUTRAL MONEY AND PRICE LEVEL STABILITY}

Despite the apparent similarities of the two theories, there are some notable differences. These differences fall into two major categories. First there are the precise ways in which inflation and deflation are 
translated into real economic effects, and second, there are each theory's implications for monetary policy. An important part of the second category is the notion of neutral money, which plays a role in both theories. Both the nominal-to-real transmission process and the issue of neutral money can be best understood as emerging from each theory's treatment of capital.

In the monetary disequilibrium deflationary story the reduction in real economic activity results from price stickiness. Again, prices and wages lag behind changes in the money supply, particularly when all are headed down. From this perspective, the economic losses of the ensuing depression are the obvious declines in economic aggregates as mutually beneficial exchanges cannot be executed. This is in contrast to the Austrian story where the economic wastes occur not during the bust part of the business cycle itself, but during the prior boom as entrepreneurs malinvest capital in response to false interest rate signals. Thus even though the economy in the aggregate appears to be doing well, it is the boom itself that is the source of the problem in the Austrian theory, while the bust (i.e., the readjustment of the capital structure) is the necessary cleansing (Rothbard 1963, p. 20).

The reason for this difference is that the Austrian story is based on a non-aggregative theory of capital that can account for the notion of malinvestment. When capital is seen not as a numerical monetary sum of physical objects, but as a structure of plans that reflect perceptions of complementarity and intertemporal coordination, it is possible to talk of malinvested capital. If one tried to attach a numerical measure to capital during the boom, it would appear to be growing and the sources of waste that the Austrian theory identifies would be overlooked. That waste is embedded within the structure of capital in the form of entrepreneurial plans that are inconsistent with consumers' intertemporal preferences. It is not that there is too much capital being created, simply capital of the wrong kind-capital that is too roundabout.

As typically presented, the monetary disequilibrium story has no serious discussion of capital and provides no real sense of any intertemporal discoordination engendered by deflation. Lacking an explicit theory of capital, it can only observe aggregate movements as evidence of a downturn. ${ }^{3}$ This is a likely explanation for the theory's almost exclusive

3. In conversation with the author, Yeager has argued that his exclusion of capital- 
concern with deflation. It is only during deflation that aggregates will quickly and obviously reveal the problem. The problems inflation generates are masked within the capital structure and are not easily revealed by macroeconomic aggregates. This presents a crucial problem for monetary policy makers. By the time most of the problems of inflation have become obvious, it is much too late to act.

The difference in the two theories' visions of capital can help to explain how each theory views the notion of neutral money and the appropriate banking policy to ensure it. In the Wicksell-Friedrich Hayek tradition, neutrality "refers to the set of conditions, under which it would be conceivable that events in a monetary economy would take place, and particularly under which, in such an economy, relative prices would be formed, as if they were influenced only by the real factors which are taken into account in equilibrium economics," (Hayek 1935, p. 130). Another way to see this conception of neutrality is that relative prices should be determined by goods-side influences only, not by money-side influences. This is in contrast to most contemporary uses of neutrality which refer to the effects of changes in the money supply on the determination of relative prices. The Wicksell-Hayek conception is a policy norm, not necessarily a feature of money as an economic institution. Both Wicksell and Hayek would have agreed that many changes in the supply of money will affect the array of relative prices, which is precisely why they wished to define the policy terms under which such affects would not take place. For most modern monetarists and New Classical economists, neutrality is a property of the money described by their models, not a policy norm. However, even within the the Austrian and monetary disequilibrium traditions, despite their common Wicksellian heritage, there are differences over what sort of policy regime would achieve neutrality within each one's framework.

Monetary disequilibrium theory, particularly in its form as modern monetarism, has historically been associated with a policy of price level stabilization. Yeager $(1986$, p. 395) refers to the benefits of a policy such as Irving Fisher's compensated dollar by saying that "under that arrangement, the whole price level would no longer have to rise or fall--painfully bucking frictions-to correct monetary disequilibrium." Warburton's (1945, pp. 307-308) discussion of the savings-investment nexus concludes

theoretic issues results from his belief that a given theory (such as cycle theory) need not tackle every single related issue. He sees capital issues as tangential to cycle theory's main concerns. Yeager's own capital theory would best be described as Casselian. 
by arguing that "only under conditions of a stable price level [does it] operate[s] with reasonable smoothness." Warburton (1981, p. 289), in a later discussion of A. C. Pigou, credited him for "noting the importance of deviations of the circulating medium from the upward trend needed for maintenance of a stable price level." Although these statements were frequently tempered, as noted below, they do reflect the essential point that the difficulty in deflationary monetary disequilibria is perceived to be the need for price level adjustments.

As Yeager (1968) and others in this tradition have rightly pointed out, "the price level" is not an isolated variable that can adjust. Money has no market of its own, and the price level is merely a composite of individual prices. However, that recognition is not translated into the policy realm. A policy of price level stabilization overlooks the fact that economic coordination takes place through the myriad of individual prices in the market.

Suppose that production increases due to a new more efficient technology. This will be reflected as an increase in $Q$ in the equation of exchange. If $Q$ rises and there is no change in monetary policy (and no presumed change in velocity), $P$ must fall to maintain the equality. If policy dictates that $P$ be stabilized, then $M$ will have to increase to offset the increase in $Q$. Thus the typical monetary disequilibrium theory proposal for a steady increase in $M$ to maintain a stable $P$.

The difficulty here, and where the Austrian view of neutrality enters the picture, is that this increase in $M$, if not called for by a change in $V$, will generate the same distortive effects on interest rates and the capital structure as would an increase in $M$ not linked to changes in $Q$. For the Austrians, the proper policy for neutrality is to maintain what Hayek $(1935$, p . 27) called the "effective amount of money in circulation," i.e., to keep $M V$ (the left side of the equation of exchange) constant. Neutral monetary policy will prevent monetarily-induced changes to $P$. What the Austrian version of neutrality will not do is stabilize $P$. Keeping $M V$ constant will cause $P$ to fall if $Q$ increases. In other words, changes in $P$ deriving from changes in aggregate supply are not problematic, while changes derived from aggregate demand (as affected by changes in $M V$ ), are to be avoided. Increased productive efficiency will lead to a fall in the overall level of prices, according to Hayek, and that fall in prices is appropriate. $^{4}$ 
Hayek's (1928) article "Intertemporal Price Equilibrium and Movements in the Value of Money" sheds additional light on this view. There Hayek argued that falling prices in response to an increase in productive efficiency is not only not detrimental, but vital, to maintaining what he called intertemporal price equilibrium (ibid., p. 100). He linked this conclusion to the role that expected prices play in the plan formation of individual market actors. Producers attempt to anticipate their time-paths of production on the basis of differences between current prices and expected prices. Presumably those prices include some consideration of the costs of production. Attempts to maintain price level stability by altering the quantity of money in response to efficiency-generated changes in prices will distort that intertemporal pattern of prices and cause time-laden errors in production. Inflation will lead to too little current production and deflation to too much current production (ibid., p. 94). Hayek's conclusion on this issue is worth quoting at length:

Theory has hitherto scarcely progressed beyond this distinction between effects of changes in the price level originating on the one hand from the 'goods side' and on the other from the 'money side.' The view advanced here, that changes in the price level coming from the 'goods side' are not merely not detrimental but are even necessary if disturbances of equilibrium are to be avoided, may still appear to many to have something of the air of paradox. This is especially so because the view that is dominant today, according to which only an invariable price level will ensure an undisturbed course of production... appears to be confirmed by general experience and the results of statistical investigations. Nevertheless the results of my analysis do not seem to me to be in any way in contradiction with the facts (ibid., p. 100).

Permitting efficiency-generated declines in prices enables entrepreneurs to more accurate gauge production over time.

Hayek's conception of the role of prices and entrepreneurial plans is rooted solidly in the Austrian theory of capital. The opening two sentences of the paper refer to the fact that all economic activity takes time and that "all linkages between economic processes necessarily involve longer or shorter periods of time" (ibid., p. 71). He explicitly states that the only previous work examining the role of prices through time is Böhm-

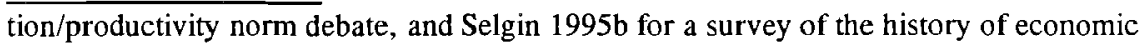
thought on this debate. 
Bawerk (ibid., p. 73) and also refers to Wicksell's and Mises' work on interest rates (ibid., p. 74). Actors have plans that unfold over time and those plans are informed by prices which have the role of "guide and regulator of all economic activity in the exchange economy" (ibid., p. 71). How particular production processes and capital goods will be used, and when they will be used, is determined by this array of intertemporal prices. When excess or deficient supplies of money are present, as in attempts to offset changes in $P$ coming from changes in $Q$, this array of prices will be distorted, providing faulty information to entrepreneurs which will be manifested as malinvested capital. Hayek argued that the appropriate monetary response to changes in $Q$ is to allow various individual prices to fall, so that the intertemporal pattern of prices can adjust to the new level of productive efficiency, by not offsetting them with an increase in the money supply. Allowing this intertemporal adjustment process to take place is what Hayek meant by neutrality. ${ }^{5}$

It now becomes more clear why monetary disequilibrium theorists can be comfortable with price level stabilization as a policy goal. As noted earlier, if one sees the adjustment costs of monetary disequilibria as being lags and stickiness in price adjustment that prevent wages and prices from falling when the supply of money does, then one is likely to see a stable price level as a desirable goal. A constantly increasing money supply will prevent falling prices, even when due to efficiency and not deficient supplies of money. If the concern, as Yeager and others point out, is how people will react to falling prices, just prevent prices from falling. However, on a more Austrian view, maintaining a stable price level will induce distortions in the capital structure that have costs of their own, even if those costs are less visible and more long term. Without a theory of capital that rests on plans, time and the role of prices, monetary disequilibrium theorists are unlikely to be convinced by Hayekian arguments against price-level stabilization. ${ }^{6}$

5. Hayek (1928, p. 99), argued that "in describing the damaging effects which can arise from money, however, it is not changes in the value of money which should be at issue, but disturbances of the intertemporal price system which are without any economic function."

6. Even Warburton and Yeager hedge their bets. In a footnote to the passage quoted earlier about the savings-investment nexus, Warburton (1945, p. 308, note 27) adds, "One possible exception to price-level stability...is a gradual fall in prices in accord with increased productivity." He then goes on to present both sides of the debate without committing himself to either. Yeager (1986, p. 395) ends the previous quote about Fisher by adding that his proposal will stabilize prices and that "the actual quantity of money would become automatically responsive to the demand for it." That phrase can be read as an endorsement of a stable $M V$ as a policy goal. However, that goal is inconsistent 


\section{A MONETARY EQUILIBRIUM RECONCILIATION}

We can attempt to reconcile the two theoretical approaches discussed above by incorporating them under the broader framework of monetary equilibrium theory (Myrdal 1939; Selgin 1988, ch. 4). The theory defines monetary equilibrium as the equality of the supply and demand for money without an intervening change in the price level. Put more dynamically, monetary equilibrium is being maintained if changes in demands for real balances are accomodated by changes in the nominal supply of money rather than changes in the price level. In terms of the equation of exchange, monetary equilibrium maintains the constancy of the left side (taking the demand for money as the inverse of income-velocity), and is equivalent to the Austrian conception of neutral money.

The usefulness of monetary equilibrium is not so much as an actual description of the banking system at any given time, but as foil against which the two possible cases of monetary disequilibrium can be compared. Those two disequilibria are the cases of an excess or deficient supply of money, i.e., inflation and deflation. The Austrian cycle theory we have been discussing corresponds to an inflationary monetary disequilibrium, while the monetary disequilibrium story can be seen as its deflationary mirror image. After a brief discussion of some other conditions of monetary disequilibrium we can return to our two theories and see them both as consistent with a monetary equilibrium theory approach to macroeconomic disturbances.

To see the full implications of monetary equilibrium, imagine a banking system like the following. Suppose that the stock of money consists of bank liabilities, which take the form of either demand deposits or hand-tohand currency, and bank reserves, which include both some base money and bank deposits in some clearinghouse system. Banks are free to establish their own individual reserve ratios, attempting to balance the profitability of further liability creation against the risk of illiquidity if reserves fall too low. If the banking system is producing the quantity of bank liabilities that the public wishes to hold at the ruling price level, the system is in monetary equilibrium. ${ }^{7}$ It is important to note that the nominal supply of money can always equal the demand for real balances

\footnotetext{
with a stable price level. Not seeing the problem here may also result from a lack of a capital theory capable of revealing the difference.

7. Selgin and White (1987) describe a possible evolutionary path that would lead to a system much like this one, and White (1984, ch. 1) and Selgin (1988, ch. 6) provide more detail on the calculations banks must undertake to maintain this balance.
} 
in the long run, given a flexible price level. In this sense, monetary disequilibrium is of necessity a short run condition, but it is precisely during the resulting long run price level adjustments, which comprise the movement from equilibrium to equilibrium, that all of the problems occur (Yeager 1986, pp. 377-78). In the Austrian theory, these adjustments are inflation's effects on relative prices and the interest rate and the resulting distortion of the capital structure. In the monetary disequilibrium story, the stickiness of prices prevents the price level from smoothly and quickly dropping so as not to affect real variables.

Due to the uniqueness of money, monetary equilibrium also implies a number of other conditions as well. The most important of these is that when the supply and demand for money are equal, in the way described, the levels of ex ante savings and investment are equal. The connection between the two conditions is that demanding bank liabilities is an act of saving, while the supply of bank liabilities is equal to the supply of funds for investment. By holding bank liabilities (i.e., not redeeming them for base money), the holder permits the bank to have control over the reserves that back them up, which is equivalent to a very short term act of saving (Brown 1910). Any attempt to reduce holdings of bank liabilities will mean a drain on the reserves of the issuing bank, and a fall in the supply of loanable funds as banks respond to the loss of reserves by shrinking their balance sheets.

At the same time, the supply of bank liabilities is related to the level of investment. The way that banks add to the money supply is through deposit creation. Faced with excess reserves, banks will induce investors in by lowering their market rates of interest. Banks create loans by adding to the borrower's holdings of bank liabilities. Banks are intermediaries between the savings supplied by liability holders and the investment funds demanded by borrowers. Bank liabilities can be seen as forms of very short term, instantly recallable credit. Holders of bank liabilities are the ultimate lenders, having given up real goods to acquire the money. Those who acquired the goods by spending the bank loan are the ultimate borrowers, having acquired goods and a promise to pay the bank.

A further condition of monetary equilibrium, directly following from the others, is the Wicksellian condition that the natural rate of interest equals the market rate (Lutz 1969, p. 106). Given that the supply of bank liabilities represents investment (the demand for loanable funds) and that the demand for bank liabilities represents savings (the supply of loanable funds), equilibrium in the money market implies equilibrium in the market for time. Thus banks are offering a market rate precisely equal to the natural rate and money loans reflect the underlying savings and investment preferences. Divergences between the two rates come when the supply 
and demand for money no longer reflect ex ante investment and saving.

It is on bank balance sheets that we see the intersection between the markets for time and money. What banks do is to loan out borrowed time in the form of money. ${ }^{8}$ When one saves, one is giving up the goods and services one could have purchased now and waiting for them until later. This sacrifice takes the form of money simply because that money represents the goods and services being given up. Savings (in the sense of sacrificing present consumption for future) is unobservable in the market, because that which is sacrificed is never seen; all we do see are the money equivalents that would have been exchanged. This relationship between the production of money and the lending of time suggests the need for an explicit theory of capital to accompany monetary equilibrium theory. In Selgin's presentation there is no explicit discussion of the role of capital, although given the general outlook of his book it can be assumed that he has implicitly adopted some variant of Austrian capital theory. Indeed, Austrian capital theory is a natural complement to monetary equilibrium theory. The investment equals savings condition as well as the natural and market rate relationship suggest that monetary disequilibria will involve some form of intertemporal discoordination. A theory of capital that can render those intertemporal effects intelligible would help to clarify the ways in which the two theories mirror each other. Austrian capital theory will be deployed to do so in the discussion below.

A final condition of monetary equilibrium is that notional demand equals effective demand. To see this, first consider Robert Clower's (1984, p. 100) aphorism: "Goods buy money, money buys goods-but goods do not buy goods in any organized market." The implication is that we cannot directly exchange our labor or capital power for goods; the process must be mediated by money. Complementary to this is Say's Law of Markets. Here it is not so much that "supply creates its own demand," but rather that "production is the source of demand." We can only demand with the resources we command due to our previous supplies of productive services. ${ }^{9}$ Before goods can be bought, productive services have to be supplied, but this process is subject to Clower's "constraint"

8. Compare Say's comment (1821b, pp. 16-17): “The value of a capital at the moment in which it is borrowed may have the form of money: but it has it only transitorily...; when we desire to use [it] as capital, we exchange [it] again for products necessary for production."

9. Compare Say 1821a, p. 60 and 1821b, p. 104. Wicksell $(1935$, p. 23) argues similarly that: "Money thus becomes his means of storing value...a pledge of guarantee-de facto not de jure-for the future performance of counter-service to which he is economically entitled by virtue of the services he has performed." 
that the exchange must take place through money. For each person's supply of productive services to be fully translatable into the ability to demand, the supply of money must be sufficient. In monetary equilibrium, production is the only source of demand, and money serves as an accurate mediator between the supply of productive commodities and services and the resulting demand for non-competing commodities. ${ }^{10}$ Say's Law is true of the market as a whole (the total amount of goods demanded depends on the total amount of services supplied) and for each individual (the ability to demand derives from the value of one's supply of productive services). ${ }^{11}$ From the monetary equilibrium benchmark we have developed, we can now re-examine the two theories in more detail.

Austrian cycle theory and monetary equilibrium. With inflation is defined as the money supply being greater than money demand at the existing price level, we can look at the Austrian theory from a monetary equilibrium vantage point. ${ }^{12}$ Inflation implies that ex ante investment exceeds ex ante savings and that the market rate of interest is below the natural rate. Both of these conditions are present in the Austrian theory of the business cycle, as discussed earlier.

Because ex post investment must equal ex post savings and ex ante investment is greater than ex ante savings during inflation, the missing savings must come from somewhere. As Myrdal (1939, p. 46) phrased it, "How does [a] tendency to disparity in the saving-investment equation develop into an ex post balance?" This excess of ex ante investment is discussed under the rubric of "forced savings." 13 The term forced savings indicates that someone else in the economy is being forced to

10. See Hutt 1979 , p. 160 on this conception of Say's Law and Selgin (1988, p. 56) and Sechrest 1993, ch. 3 for more on the link between Say's Law and monetary equilibrium.

11. On this issue also see Glasner 1989 , p. 205 . He argues that monetary equilibrium "occurs without impinging on the real sector of the economy, which is the fundamental proposition that both Say's Identity and the Law of Reflux seek to establish."

12. As has been noted elsewhere (Horwitz 1988, pp. 169-70), this definition of inflation is a problematic one for a few Austrians. Mises $(1912, \mathrm{pp} .161,272)$ adheres to this definition as does Hayek (n.d., p. 12), but Rothbard (1962, p. 307, note 8) defines inflation as "an increase in the money supply not consisting in an increase in the money metal." Rothbard's definition is different from the monetary equilibrium view in that he ignores the demand for money (or at least assumes that it moves in lock-step with the supply of money metal).

13. On the concept of forced savings, see the similar discussions in Hayek 1939, pp. 183 ff, Robertson 1928, p. 43 and 1957, pp. 70 ff, Cassel 1927-28, p. 332 and Selgin 1988 , p. $60 \mathrm{ff}$. 
restrict their consumption to finance the additional claims to resources provided to the recipients of the excess bank liabilities. The forced savers are the existing holders of money. Their ability to consume is impaired by the influx of new purchasing power represented by the excess supply of money. Those who receive the excess dollars get an increase in their proportional (to the total amount of dollars) claims over resources, while the proportional claims contained in previous holders' dollars are diluted by the increase in the total amount of dollars available for purchasing goods and services.

Another way to look at the same issue is through Say's Law. An excess supply of money means that for the recipients of the forced savings, their effective demand is greater than their notional demand, i.e., their monetary purchasing power is greater than the real value of the productive services they have supplied. The receipt of the excess money no longer reflects previous supplies, because the new recipients earn their purchasing power through either sheer luck or by being at the right place in the money supply process (Wagner 1977, p. 406). This redistribution to the new recipients sets off the relative price effects (and resulting distortions) that are part of the traditional Austrian story.

The argument is that changes in the money supply do not affect all prices equiproportionately. As a result, those goods whose relative prices rise tend to attract relatively non-specific inputs from elsewhere in the structure of production, while the other producers see those inputs bid away. This is consistent with the observation that the resulting switchover of even slightly specific capital goods to uses other than their original ones entails adjustment costs and short run production inefficiencies (Horwitz 1991). These relative price effects happen precisely because of the split between notional and effective demand. Relative price effects are another way of saying that purchasing power and the decisions that result no longer reflect the real value of productive services. Therefore the prices determined by that purchasing power also no longer reflect true market values.

What inflation does is disrupt economic coordination in all non-money markets. Coordination at the microeconomic level is hampered by the discoordination in the money market. The split between effective and notional demand distorts the array of relative prices, causing inappropriate decisions by agents who rely on these prices. In particular, time-laden decisions are distorted due to the money-capital relationship in the banking system. Since the market rate is the only visible manifestation of underlying time preferences, if it is an incorrect reflector of time preferences, then entrepreneurs lose the only reliable time preference indicator they have. An Austrian conception of capital enables us to see the resulting 
distortions.

Deflation and monetary equilibrium. If we define deflation as an excess demand for money at the existing price level, we can examine the monetary disequilibrium theory story in terms of monetary equilibrium theory and the Say's Law process. Where during inflation there was a redistribution of demand away from the value of an individual's supply of productive services, during deflation purchasing power is less than the value of those services. Somewhere between the attempt to supply productive services and the resulting demand for non-competing commodities there has been a "leak." The leak is that the deficient supply of money constrains the Say's Law process from effectively transforming the ability to supply productive services into effective demand.

Analogous to the forced savings of inflation, deflation involves forced investment. Since savings and investment must be equal ex post, but are different ex ante, the excess saving must be matched by investment coming from somewhere. This investment is visible on store shelves as accumulating stocks of unsold goods. Firms did not want ex ante to invest in so much inventory, but the restriction of consumption (or excess of savings) imposed on those who would have received money and spent it, if it were in correct supply, causes these increasing inventories. Looking from the perspective of the firm's total income, the restriction of consumption income due to the deficient money supply must imply increased unintended investment.

Austrian capital theory can provide some additional insights here. Due to the falsely high interest rate, producers have made their production processes too short. The reduction in available capital leads entrepreneurs to shift away from longer-term, more capital-intensive, projects to shorter ones that will more quickly deliver consumer goods. The lack of coordination with consumers' real preferences is revealed as unwanted inventory accumulation. Again this is analogous to the discoordination in the Austrian theory which is revealed as unfinishable capital projects. The deflationary story is also one of relative price effects. The places where money is relatively more absent will be places where prices fall relatively more. These new and distorted price signals, along with the higher market rate of interest, will turn capital away and send the signal that shorter processes are more profitable.

As with inflation, the effects of disequilibrium in the money market are felt across the whole economy, reducing the coordinative powers of all other markets. Deflations are ragged just like inflations, and in the same way we cannot trace the path of excess issues of money, we cannot know precisely which areas are differentially affected by the lack of money. Who would have been hired if money had been available? These distor- 
tions in the array of relative prices upset microeconomic and intertemporal coordination in the same way that inflation does.

This is where capital theory enables us to advance over the traditional presentation of monetary disequilibrium theories of deflation. Rather than seeing the costs of deflation as deriving only from the lagging of prices and wages behind the nominal money supply, we can also comprehend the distortions in the capital structure, and subsequent adjustment costs, that false interest rate and price signals will engender. Much as the Austrian cycle theory is a systematic presentation of the distorted patterns in the capital structure, one can offer an analogous presentation for deflationary monetary disequilibria. A deflation story enhanced by capital theory would also offer those sympathetic to Austrian cycle theory a reason for taking the effects of deflation seriously. Austrians have been too quick to dismiss the effects of deflation, perhaps because of its relative rarity in the real world. The monetary disequilibrium story can also offer an account of the secondary deflation that some argue follows the bust in Austrian cycle theory. ${ }^{14}$ With both theories under a common theoretical framework, they can be simultaneously deployed to help interpret historical periods of monetary disequilibrium.

\section{CONCLUSION}

Macroeconomics should recognize that microeconomic coordination is ultimately what economies try to achieve. To facilitate that coordination, a coordinated money market is necessary because the pervasiveness of money implies that discoordination in the money market will lead to discoordination in all markets. Monetary disequilibria cannot be isolated to the money market.

This perspective suggests that explanations for depressions should look for ways in which historical or actual monetary regimes permit significant deviations from monetary equilibrium. Consistent patterns of monetary disequilibria may reflect a faulty regime rather than mistaken policies within that regime. If so, policy discussions should focus on alternative

14. Rothbard (1962, p. 865) argued that deflation, especially after a previous inflation, was not problematic: "It may well be true that the deflation process will overshoot the free market equilibrium point and raise price differentials and the interest rate above it. But if so no harm will be done since a credit contraction can create no malinvestments and therefore does not generate another boom-bust cycle." To argue that deflation causes no harm completely overlooks the sort of issues raised by monetary disequilibrium theory. If prices do not fall smoothly, distorted production and consumption decisions will result as will a decline in aggregate economic activity. 
monetary regimes rather than which policy direction is appropriate for the existing regime (Buchanan 1983). One major advantage of viewing Austrian cycle theory and monetary disequilibrium theory through a monetary equilibrium framework is that discussions of the desirability of various monetary regimes come to the forefront. Alternative monetary regimes can be evaluated by their ability to maintain, or penalize deviations from, monetary equilibrium. A number of recent proposals for monetary reform can be seen as attempts to explain or devise monetary institutions that can maintain monetary equilibrium. ${ }^{15}$

This perspective is even more powerful when the role of capital is made explicit. A monetary regime that can approximate monetary equilibrium to the greatest degree possible will prevent the capital structure distortions generated by inflation and deflation. In so doing, it will enable society to avoid the adjustment costs associated with undistorting the capital structure in the wake of monetary disequilibria. The capital structure is where the most powerful effects of monetary disequilibria occur. When properly grounded in a good theory of capital and the framework of monetary equilibrium theory, the Austrian inflation story and the monetary disequilibrium deflation story provide persuasive and complementary accounts of the effects of monetary disequilibria.

\section{REFERENCES}

Böhm-Bawerk, Eugen. 1923. The Positive Theory of Capital, Stechert, New York.

Brown, Harry G. 1910. "Commercial Banking and the Rate of Interest," Quarterly Journal of Economics, 24, 743-49.

Buchanan, James M. 1983. "Monetary Research, Monetary Rules, and Monetary Regimes," Cato Journal, 3, no. 1, Spring, 143-46.

Cassel, Gustav. 1927-28. "The Rate of Interest, the Bank Rate, and the Stabilization of Prices," reprinted in AEA Readings in Monetary Theory, Blakiston Company, New York, 1951.

Clower, Robert W. 1984. "Introduction to Monetary Theory: Selected Readings," reprinted in Donald Walker, ed., Money and Markets, Cambridge University Press, Cambridge, 1988.

Davenport, Herbert J. 1913. The Economics of Enterprise, Augustus M. Kelley, New York, 1968.

15. For Austrian perspectives see Hayek 1978, White 1984, Selgin 1988, and Horwitz 1992. For a monetary disequilibrium perspective see Greenfield and Yeager 1983 and Woolsey 1992. 
Dowd, Kevin. 1995. "Deflating the Productivity Norm," Journal of Macroeconomics, 17, no. 4, Fall, 717-32.

Garrison, Roger. 1984. "Time and Money: The Universals of Macroeconomic Theorizing," Journal of Macroeconomics, 6, no. 2, Spring, 197-213.

Glasner, David. 1989. "On Some Classical Monetary Controversies," History of Political Economy, 21, no. 2, Summer, 201-29.

Greenfield, Robert L. 1994. Monetary Policy and the Depressed Economy, Wadsworth, Belmont.

Greenfield, Robert L. and Leland B. Yeager. 1983. "A Laissez-Faire Approach to Monetary Stability," Journal of Money, Credit, and Banking, 15, no. 3, August, 302-15.

Hayek, F. A. 1928. "Intertemporal Price Equilibrium and Movements in the Value of Money," reprinted in Roy McCloughry, ed., Money, Capital and Fluctuations: Early Essays, University of Chicago Press, Chicago, 1984.

1933. Monetary Theory and the Trade Cycle, Augustus M. Kelley, New York, 1966.

. 1935. Prices and Production, Augustus M. Kelley, New York, 1967.

1939. Profits, Interest and Investment, Augustus M. Kelley, Clifton, N.J., 1975.

1978. The Denationalisation of Money, Institute for Economic Affairs, London.

. n.d. "The Muddle of the Middle," unpublished ms, part of an early draft of The Fatal Conceit, University of Chicago Press, Chicago, 1988.

Horwitz, Steven. 1988. "Misreading the 'Myth': Rothbard on the Theory and History of Free Banking," reprinted in Peter J. Boettke and David L. Prychitko, eds., The Market Process: Essays in Contemporary Austrian Economics, Edward Elgar, Aldershot, 1994.

1991. "The Political Economy of Inflation: Public and Private Choices," Durell Journal of Money and Banking, 3, no. 4, November, 26-37.

1992. Monetary Evolution, Free Banking, and Economic Order, Westview Press, Boulder.

Hutt, William H. 1979. The Keynesian Episode, Liberty Press, Indianapolis.

Lachmann, Ludwig. 1978. Capital and Its Structure, Sheed Andrews and McMeel, Kansas City.

Leijonhufvud, Axel. 1981a. "Effective Demand Failures," in idem, 
Information and Coordination, Oxford University Press, New York, 1981.

1981b. "The Wicksell Connection: Variations on a Theme," in idem, Information and Coordination, Oxford University Press, New York, 1981.

. 1988. "Did Keynes Mean Anything? Rejoinder to Yeager," Cato Journal, 8, no. 1, Spring/Summer, 209-17.

Lewin, Peter. 1994. "Knowledge, Expectations and Capital: The Economics of Ludwig M. Lachmann," Advances in Austrian Economics, 1, JAI Press, Greenwich, 233-56.

Lutz, Friedrich A. 1969. "On Neutral Money," in E. Streissler et. al., eds., Roads to Serfdom: Essays in Honour of F. A. Hayek, Routledge and Kegan Paul, London.

Mises, Ludwig von. 1912. The Theory of Money and Credit, Liberty Press, Indianapolis, 1980.

1966. Human Action, Henry Regnery, Chicago.

Myrdal, Gunnar. 1939. Monetary Equilibrium, Augustus M. Kelley, New York, 1965.

Robertson, Dennis H. 1928. "Theories of Banking Policy," reprinted in Essays in Monetary Theory, Staples Press, New York, 1940. . 1957. Money, University of Chicago Press, Chicago.

Rothbard, Murray N. 1962. Man, Economy, and State, Nash Publishing, Los Angeles.

1963. America's Great Depression, Richardson and Snyder, New York, 1983.

Say, J.-B. 1821a. "Letters to Mr. Malthus," in idem Letters to $\mathrm{Mr}$. Malthus and A Catechism of Political Economy, Augustus M. Kelley, New York, 1967.

. 1821b. "A Catechism of Political Economy," in idem, Letters to Mr. Malthus and A Catechism of Political Economy, Augustus M. Kelley, New York, 1967.

Sechrest, Larry J. 1993. Free Banking: Theory, History, and a LaissezFaire Model, Quorum, Westport.

Selgin, George A. 1988. The Theory of Free Banking: Money Supply Under Competitive Note Issue, Rowman and Littlefield, Totowa. . 1995a. "The Case for a 'Productivity Norm': Comment on Dowd," Journal of Macroeconomics, 17, no. 4, Fall, 733-40.

1995b. "The 'Productivity Norm' versus Zero Inflation in the History of Economic Thought," History of Political Economy, 27, no. 4, Winter, 705-35.

Selgin, George A. and Lawrence H. White. 1987. "The Evolution of 
a Free Banking System," Economic Inquiry, 25, July, 439-57.

Wagner, Richard. 1977. "Economic Manipulation for Political Profit: Macroeconomic Consequences and Constitutional Implications," Kyklos, 30, no. 3, 395-410.

Warburton, Clark. 1946. "The Misplaced Emphasis in Contemporary Business Fluctuation Theory," reprinted in AEA Readings in Monetary Theory, Blakiston Company, New York, 1951.

1966. Depression, Inflation, and Monetary Policy, Johns Hopkins Press, Baltimore.

1981. "Monetary Disequilibrium Theory in the First Half of the Twentieth Century," History of Political Economy, 13, no. 2, Summer, 285-99.

White, Lawrence H. 1984. Free Banking in Britain, Cambridge University Press, Cambridge.

Wicksell, Knut. 1898. Interest and Prices, Augustus M. Kelley, New York, 1965.

. 1935. Lectures in Political Economy, 2: Money, Routledge and Kegan Paul, London, 1950.

Woolsey, W. William. 1992. "A Model of the BFH Payments System," Southern Economic Journal, 59, no. 2, October, 260-72

Yeager, Leland B. 1968. "Essential Properties of the Medium of Exchange," Kyklos, 21, January/March, 45-69.

1986. "The Significance of Monetary Disequilibrium," Cato Journal, 6, no. 2, Fall, 369-99.

\section{COMMENT ON HORWITZ'S ARTICLE}

BY

\section{ALLIN COTTRELL}

Austrian economics is arousing increasing interest, not to say enthusiasm, these days. No doubt this is in part due to the collapse of the planned economies of the Soviet type, which has lent credibility to the claims of Ludwig von Mises and Friedrich Hayek regarding the impossi-

Wake Forest University. 
bility of rational economic calculation under socialism-claims which were disputed by the mainstream neoclassical economists of a generation ago. The phenomenon also reflects a relatively long-standing dissatisfaction with neoclassical economics. For many years it was the radical critics of capitalism who felt most keenly the attractions of alternative approaches in economics. Now, increasingly, champions of the market are coming to believe that neoclassical theory does not offer a deep and firm enough basis for asserting the virtues of the market system, and the counterproductive effects of government intervention therein.

Very well; one welcomes an extension of the scope of debate within economics. One does not, however, welcome the repetition of partisan positions as received wisdom, without regard to cogent criticisms that have been made of those positions. My main criticism of the paper by Steven Horwitz (1996) in this journal is that it seems to exemplify this temptation. The stated object of Horwitz's paper is to compare the Austrian business cycle theory of Ludwig von Mises and Friedrich Hayek with the "preKeynesian" monetary disequilibrium theory stemming from Clark Warburton and H. J. Davenport, and more recently espoused by Leland Yeager and Leland Greenfield. Both of these theories are concerned with ways in which the coordination of economic activities may become disrupted by disequilibria in the "markets for time and money." Horwitz suggests that, despite certain apparent differences, the theories can be reconciled within the "monetary equilibrium" perspective developed by George Selgin, provided that the latter is enchanced via the incorporation of insights from Austrian capital theory-and that the resulting combination provides the basis for an adequate macroeconomics. (Neither Keynesian nor New Classical macroeconomics come in for discussion; presumable they are not sufficiently "coordination-based" to be considered of any interest.)

Considered as an exercise in the history of economic thought, the paper is lacking in that the "monetary disequilibrium" school is given short shrift, Horwitz reckoning that a "stylized composite" of the views of the early writers-H. G. Brown, Davenport and Warburton (as filtered by Yeager) is sufficient for his purposes. Basically, the paper is a piece of advocacy for (an augmented version of) Hayek's cycle theory. There is nothing wrong with that per se, but in the context of the modern debate over Hayek's theory, Horwitz's terms of reference are very narrow. Almost all of the modern references are to Austrians and Austriansympathizers. Horwitz does not mention, let alone engage with, the body of recent critical work on this theory (e.g., Lawlor and Horn 1992; Cottrell 1994; Laidler 1994; and see also Trautwein 1996).

Besides the point that the discussion of Hayek's cycle theory seems to 
me uncritical, I have two further objections: Hayek's views are presented in an over-simplified manner, and the attempt to marry his cycle theory with the "monetary disequilibrium" approach favored by some modern fellow-travelers of Austrian economics is theoretically unprincipled.

To begin with the over-simplification of Hayek: Horwitz writes that "the traditional Austrian story is that [the] cause of the divergence between the market rate and the natural rate is the activity of the banking system," and in a footnote he remarks that it's "curious" that Wicksell did not trace this divergence to "errors of commission by the banking system," but rather emphasized the possibility that technological change might "alter the natural rate without an appropriate reponse...by the banking system."

Wicksell's position is not at all curious. It is an obvious response to what J. M. Keynes (in the Treatise on Money) was to call the "Gibson paradox," namely the tendency for interest rates to move pro-cyclically. If interest rates are typically low, not high, in times of deflation and recession, then the deflation cannot be ascribed to an arbitrary increase in the market rate on the part of the banks. If the Wicksellian theory is to hold any water, it must rather be that the banking system has failed to lower the market rate sufficiently in the facr of a fall in the natural rate. And symmetrically for the case of high interest rates at times of boom and inflation: the inflation cannot be due to an arbitrary cut in market rate, but must be due to the rise in market rate lagging an increase in the natural rate.

Hayek was well aware of all this, and made a point of stating his agreement with Knut Wicksell, most notably in Monetary Theory and the Trade Cycle (Hayek, 1966, pp. 147-8, 168). Besides, the casual ordering is wrong in Horwitz's discussion. For both Wicksell and Hayek the main line of analysis is one in which the quantity of money is endogenous. It is not that the banks raise money supply, and so the rate of interest falls; it is divergence between the market and natural rates that drives changes in bank lending and therefore money stock.

My second main point concerns an issue where the over-simplification of Hayek and an uncritical attitude toward Hayek go hand in hand. The argument in Horwitz's paper retails Hayek's proposition that in order to achieve monetary neutrality, it is necessary to hold constant the product of money stock and velocity rather than aiming at a stable price level. This discussion ignores Hayek's own quite significant qualifications of his prescription (Hayek 1935, pp. 113-125, 131, 161), as well as the severe problems the theory faces even when qualified. Hayek's idea is that maintaining price stability in the face of increasing real output requires an increase in money supply, and that this will give rise to the same distortions as an inflationary lowering of the interest rate. But in 
his basic theory, it is not monetary expansion per se that causes trouble; it is monetary expansion unbalanced in favor of investment (and hence generating "forced saving"). If, on the other hand, it is generally understood that the monetary authority is aiming at price stability in the face of real growth, and a stable price level is therefore anticipated, there is simply no reason to presume that the expansion must be unbalanced in this way (see also Sraffa 1932 on this point). The wage bill will be rising over time, and a proportional part of the monetary expansion will take the form of working-capital loans to firms to finance this increase in ware-payments-i.e., it will indirectly finance an increase in consumption, in step with the increase in investment that will no doubt be occurring too.

In addition, Horwitz's apparent enthusiasm for the policy of maintaining a constant value of $M$ times $V$ in the face of real growth is hard to square with his implicit approval of the idea that prices and wages tend to be sticky downward (in the context of the "monetary disequilibrium" analys is of deflation in section III). This brings me to my point about the unprincipled nature of the conciliation that Horwitz attempts.

In Horwitz's exposition of monetary disequilibrium theory, the banks trigger recession by cutting the supply of money. "The banking system fails to produce a sufficient supply of money, reducing bank reserves and restricting their ability to make new loans." This is rather opaque, but I presume it must mean that the central bank reduces bank reserves, hence restricting the ability of the commercial banks to make loans. Then "[w]ith a smaller pool of funds to lend out, banks are forced to raise their market rates of interest."

What are we to make of a theory which proposes to explain recessions via prior, exogenous, reductions in money supply? First of all, this is a prime case of the sort of "false steps by bankers" theory that Hayek (1966, p. 145) considered inadequate; in addition, it would appear to be of little relevance to the postwar world. To generalize the theory in order to give it any grip on the world after the 1930s one would have to take a time-derivative and talk in terms of a slowdoen in the rate of monetary expansion rather that an actual cut in money supply. But this would emphasize the outright inconsistency with Hayek's theory, in which a slowdown of monetary expansion is always a step in the right direction.

According to Hayek's cycle theory, recession is an indirect and delayed response to excessive monetary expansion-generated endogenously by a situation in which the market rate stands below the natural rate of interest. According to the monetary disequilibrium theory, recession is the fairly direct result of exogenous monetary contraction. Despite Horwitz's talk of "similarities," these threories are in the head-on compe- 
tition, and the notion of reconciliation of the two seems quite implausible.

The air of implausibility is not dispelled by Horwitz's first step in this direction. The reconciliation is supposed to proceed by nesting the two theories within the general framework of "monetary equilibrium." We are told, first, that "monetary equilibrium is being maintained if changes in demands for real balances are accommodated by changes in the nominal supply of money rather than changes in the price level," and second, that this conception is "equivalent to the Austrian conception of neutral money." Rather than being equivalent, these ideas are directly contradictory. Horwitz has just finished arguing that Hayekian neutrality requires that the increased demand for real balances associated with real economic growth be accommodated precisely by a fall in the price level and not an expansion of nominal money supply. The reconciliation project seems to depend on the author's promptly forgetting those elements of each theory that are problematic for the other.

The various aspects of Horwitz's paper to which I have drawn attention above (simplification of Hayek, uncritical acceptance of the latter's cycle theory, and the proposed marriage between Hayek and modern preKeynesians) have a common drift or tendency, even if it remains somewhat between the lines-namely, the promulgation of the view of the market system as a finely self-adjusting mechanism, perturbed by inept government intervention. This is not the place to present an alternative conception; but I hope to have raised the suspicion that Horwitz's arguments provide little support for the view he espouses.

\section{REFERENCES}

Cottrell, Allin. 1994. "Hayek's Early Cycle Theory Re-examined," Cambridge Journal of Economics, 18, 197-212.

Hayek, Friedrich A. 1935. Prices and Production, revised ed., Routledge, London.

Hayek, Friedrich A. 1966. Monetary Theory and the Trade Cycle, Augustus M. Kelley, New York.

Horwitz, Steven. 1996. "Capital Theory, Inflation and Deflation: The Austrians and Monetary Disequilibrium Theory Compared," Journal of the History of Economic Thought, this issue.

Keynes, J. M. 1930. A Treatise on Money, 2, Macmillan, London.

Laidler, David. 1994. "Hayek on Neutral Money and the Cycle," in Marina Colonna and Harald Hagemann, eds. Money and Business Cycles: The Economics of F. A. Hayek, 1, Edward Elgar, Aldershot. Lawlor, Michael S. and Bobbie L. Horn. 1992. "Notes on the Sraffa- 
Hayek Exchange," Review of Political Economy, 4, 317-40.

Sraffa, Piero. 1932. "Dr. Hayek on Money and Capital," Economic Journal, 42, March, 42-53.

Trautwein, Hans-Michael. 1966. "Hayek's Wicksellian Dichotomy," History of Political Economy, 28, Spring, 27-55. 


\section{REPLY TO COTTRELL}

BY

\section{STEVEN HORWITZ}

Allin Cottrell's criticisms of my paper fall into three general categories: criticisms of the paper I did not write, criticisms of the paper I claimed to write, and criticisms of the paper he thinks I was really writing. Let me try to address each of these categories, emphasizing the more substantive points he raises about the paper I claimed to write.

As for the paper I did not write, Cottrell complains that I ignored both the New Classical and New Keynesian literature, as well as recent work critical of Friedrich Hayek's business cycle theory. Guilty as charged on both counts. I did not, however, intend for the paper to be a comprehensive examination of Hayek's cycle theory and a comparison of that theory with all contenders. Such a project would be well beyond the scope of a journal article. ${ }^{16}$ My purpose was more narrow, and far more modest.

The Austrian revival that Cottrell mentions has been heavily oriented toward microeconomics, by developing Hayek's and Israel Kirzner's work on competition and entrepreneurship, and methodology, by exploring the philosophical grounding of the distinctiveness of Austrian economics. Much less attention has been paid to macroeconomic issues. ${ }^{17}$ Aside from the contributions of Roger Garrison and some important recent work by George Selgin, there has not been much new in Austrian macroeconomics in the recent revivial. My purpose in this paper was to try to provide a framework for doing precisely this kind of work.

16. I am, however, in the process of undertaking a broader look at Austrian macroeconomics in my book manuscript referred to in the paper's acknowledgements.

17. I am excluding George Selgin's (1988) and Lawrence White's (1996) work on free banking, as it more properly belongs to monetary economics or monetary policy than to macroeconomics. 
In the sense that I was trying to set out an Austrian perspective on macroeconomic theory, it would be fair to call the paper a piece of "advocacy." However, I do not think the charge that I have ignored the critical literature on Hayek as well as the other schools of thought is a fair one, given the aim of the paper. I would hope that there is a place in economics for attempting to push forward particular approaches from, as it were, the inside. For that kind of forward-looking theory-building project it would seem acceptable to treat the received doctrine somewhat uncritically as one attempts to get a handle on some of its implications. To expect those trying to develop Austrian economics to always tackle all of the critical literature in every paper would prevent the Austrian approach from advancing on its own grounds.

Even so, I conceived of the paper not as a mere "repetition of partisan positions," but as an attempt to point out to Austrians why it is important to think about deflationary monetary disequilibria and why the work of Leland Yeager, a well-known critic of Austrian cycle theory, should be taken seriously by Austrians. Austrians have historically been quite dismissive of any adverse effects of deflation (e.g., Murray Rothbard's position explained in note 14), and I hoped to remedy that. Historically, of course, many one-time Austrians (such as Gottfried Haberler) abandoned Austrian cycle theory precisely because it had trouble explaining the secondary downturn. Bringing together the monetary disequilibrium approach and the Austrian theory under one umbrella offers a way to fix that problem. Conversely, I hoped that Yeager, Robert Greenfield, and others would see the common Wicksellian heritage of their work and that of the Austrians. I must confess my surprise at being labelled as an Austrian "partisan" in a paper whose express purpose was to open up Austrian macroeconomics to contributions from people who would not generally be considered Austrians.

My "advocacy" is not to claim that Austrian cycle theory was perfected for all time in the 1920s and '30s. There is much work that needs to be done to bring the theory up to date with the latest work in economic theory and changes in economic institutions. But again, my goal was simply to lay out an organizing framework for that endeavor by trying to take what was good out of both Austrian cycle theory and monetary disequilibrium theory. If that is "advocacy" so be it. It seemed to me that noting important similarities between thinkers who have criticized or ignored each other's work, and showing how those similarities could be used to analyze macroeconomic phenomena, was more than mere advocacy.

Regarding Cottrell's criticisms of the paper I claimed to write, I will address several of them in the order they are raised. His first point 
concerns the Austrian view that cycles necessarily arise when the monetary authority intentionally overexpands the money supply and drives the market rate below the natural rate. He contends that view fails to address Knut Wicksell's argument that the far more likely cause is movements in the natural rate unmatched by changes in the market rate. Cottrell's point is well taken, but I am not sure it does grave damage to the broader argument I raised. Whatever the cause of the divergence between the market rate and the natural rate, the intertemporal discoordination that is the distinctive characteristic of the Austrian model will nonetheless arise. The key issue is that the market price that is supposed to reflect people's underlying intertemporal preferences (the market rate) no longer accurately does so. When the two rates are out of synchronization, one or the other Wicksellian cumulative process will follow, regardless of the initiating factor. The mismatch of the two rates might be due to an intentional over-expansion by the banking system, or the banking system's inability to keep up with movements in the natural rate, or regulatory interventions that distort market rates of interest (see Garrison 1993, for example). Cottrell is right to say that Wicksellian processes can be caused by a number of factors, but I do not believe that undermines the underlying point that it is divergences in the two rates of interest that are a defining characteristic of monetary disequilibrium.

Cottrell's later point that deflationary disequilibria in the post-war world are likely better understood as slowdowns in the rate of monetary expansion (given the expectation of that expansion), rather than outright reductions in the money supply, is also well-taken. A more complete version of the monetary equilibrium perspective I have outlined should take such expectational issues into consideration. In addition, I would think that a modernized version of this approach would also have to consider the various financial innovations that have taken place in the last few decades and how they affect the financing options facing entrepreneurs in the face of changes in the money supply or bank interest rates. It is precisely these kind of theoretical and institutional issues that should be incorporated into the theory. I certainly have not done so in the paper under discussion, but then I did not make any grand claims to providing a detailed and updated presentation of Austrian business cycle theory.

Cotttrell's final point of substance is that the policy of allowing the price level to fall in the face of an increase in real income, what Selgin (1995a) refers to as the "productivity norm," is problematic. One part of this point is that such a policy is contradictory with my claim that prices and wages exhibit downward stickiness. The other is that there is a contradiction between Hayekian neutrality (which requires a fall in the price level to offset the increased demand for real balances that is 
associated with real economic growth) and the monetary equilibrium norm of adjusting the nominal money supply to changes in the demand for money rather than allowing adjustments to occur through the price level. In re-reading my paper, I admit a lack of clarity in that discussion, so let me see if I can sort it out here.

The policy of allowing the price level to fall when real income rises is best understood in terms of increases in real income that result from increases in factor productivity, hence the "productivity norm." ${ }^{18}$ This has two consequences for Cottrell's criticism. First, prices and wages are far less likely to be sticky in either direction when the price changes in question are precisely what resource owners are trying to do. Productivity gains occur, and output prices fall, because entrepreneurs intend those results to occur; thus the appropriate price changes are not problematic (Selgin 1990, p. 280). The price changes required by monetary disequilibria are more difficult to effect precisely because they are not the intention of any particular entrepreneur, setting up the game-theoretic "who-goes-first" problem noted by Yeager and Greenfield, as well as some New Keynesians.

This argument also serves as a response to the second half of Cottrell's concern. The growth in real income associated with gains in productivity will indeed produce an increase in the absolute demand for real money balances. However, because that productivity gain is intended by entrepreneurs, output prices will react very quickly to a fall in the unit cost of production. ${ }^{19}$ The result is that the increased demand for real balances is accomodated by this appropriate and unproblematic fall in output prices . Cottrell is right to point to this problem, as my paper fails to distinguish between the stickiness of price changes that are necessitated by changes in supply versus those necessitated by changes in aggregate demand (see Selgin 1995b, p. 735, n.2). Prices will be far more sticky when the need for change is coming from changes in aggregate demand than they will be when the need for change is a result of a firm or industry-specific increase in productivity. Put differently, under the productivity norm, changes in velocity (the demand for money relative to income) should be accomodated by changes in the nominal money supply, while absolute changes in the demand for real balances, such as those associated with productivity-driven changes in real income, are quite easily met by

18. For more on these issues, see Dowd 1995 and Selgin 1990, 1995a, 1995b.

19. Lest $I$ be accused of citing only Austrians and fellow-travelers, consider Arthur Okun's (1980, p. 169) claim that output prices are "much more responsive to changes in costs than to shifts in demand." 
changes in individual prices, and, therefore, the price level.

Let me finally address Cottrell's complaint about the paper he thinks I was really writing, namely the supposed "between the lines" tendency of portraying the market as a "finely self-adjusting mechanism, perturbed by inept government intervention." Try as I might, I cannot find anything in the paper that would suggest the sort of policy position that Cottrell claims I am taking. In fact, I was studiously careful to avoid any policy issues in the paper, even to the point of referring to the "banking system" rather than the "central bank" in my discussion of the Austrian cycle theory. As written, the paper claims merely that however well markets facilitate coordination, monetary disequilibria (which the paper does not necessarily blame on "inept government intervention") will make coordination worse. If Cottrell sees some sort of subliminal ideological drift in that argument, perhaps he is seeing it through ideology-colored glasses of his own. I apologize for disappointing anyone looking for a deeper message, but, once again, the task of the paper under discussion was simply to stake out some intellectual territory for a broadly Austrian macroeconomics by trying to reconcile two lines of thought that share a common ancestry in Wicksell. I leave it to the reader to judge whether I have succeeded.

\section{REFERENCES}

Dowd, Kevin. 1995. "Deflating the Productivity Norm," Journal of Macroeconomics, 17, no. 4, Fall, 717-32.

Garrison, Roger. 1993. "The Roaring Twenties and the Bullish Eighties: The Role of Government in Boom and Bust," Critical Review, 7, nos. 2/3, Spring/Summer, 259-76.

Okun, Arthur. 1980. Prices and Quantities: A Macroeconomic Analysis, Brookings Institution, Washington.

Selgin, George A. 1988. The Theory of Free Banking: Money Supply Under Competitive Note Issue, Rowman and Littlefield, Totowa.

1990. "Monetary Equilibrium and the Productivity Norm of Price-Level Policy," Cato Journal, 10, Spring/Summer, 265-87.

1995a. "The 'Productivity Norm' versus Zero Inflation in the History of Economic Thought," History of Political Economy, 27, no. 4 , Winter, 705-35.

- 1995b. "The Case for a 'Productivity Norm': Comment on Dowd," Journal of Macroeconomics, 17, no. 4, Fall, 733-40.

White, Lawrence H. 1996. Free Banking in Britain, 2d ed., Routledge, New York. 